\title{
Alkitab: Penyataan Allah Yang Diilhamkan
}

\author{
Djoko Sukono \\ Sekolah Tinggi Teologi Baptis Indonesia Semarang \\ djokosukono9@gmail.com
}

\begin{abstract}
ABSTRAK
Para teolog juga mempunyai pandangan yang berbeda mengenai Alkitab. Pandangan Liberal atau Neo-Liberal, tokohnya seperti Rudolf Bultmann. Pandangan ini berpegang pada konsep bahwa untuk mengerti secara tepat kebenaran Alkitab, sesorang harus melakukan demitologisasi Perjanjian Baru mengenai Kristus. Kristus dapat dilihat sebagi tokoh mitos daripada sebagai tokoh Historis dalam Alkitab. Bagi Bultmann, yang penting adalah berita tentang Kristus, tetapi bukan kesejarahan-Nya. Allah memipin para penulis sehingga mereka menuliskan pesan-Nya dalam Alkitab.
\end{abstract}

Kata kunci: Alkitab, tanpa salah, Ortodoks, Firman, Allah.

\section{PENDAHULUAN}

Alkitab merupakan salah satu buku yang paling misterius, yang sangat sering disalahpahami, dan yang paling banyak mengalami salah kutip sepanjang jaman. Banyak orang yang menganggap Alkitab sebagai Firman Allah yang diwahyukan, sempurna, tidak mungkin keliru, tetapi juga banyak di antaranya yang dikutip secara tidak akurat, dipakai sebagai rujukan secara tidak tepat untuk menyampaikan pesanpesan tertentu. Para teolog juga mempunyai pandangan yang berbeda mengenai Alkitab. Pandangan Liberal atau Neo-Liberal, tokohnya seperti Rudolf Bultmann. Pandangan ini berpegang pada konsep bahwa untuk mengerti secara tepat kebenaran Alkitab, sesorang harus melakukan demitologisasi Perjanjian Baru mengenai Kristus. Kristus dapat dilihat sebagi tokoh mitos daripada sebagai tokoh Historis dalam Alkitab. Bagi Bultmann, yang penting adalah berita tentang Kristus, tetapi bukan kesejarahan-Nya.

Pandangan Neo - Ortodoks dengan tokohnya antara lain Karl Barth. Menurut pandangan ini, Alkitab berisi Firman Allah, tetapi Alkitab bukan benar-benar Firman Allah. Barth beranggapan tidak pantas bagi Allah untuk menyampaikan Kristus yang transeden melalui cara yang rendah, berupa proposisi-proposisi logis pada halaman-halaman yang dicetak. Jadi menurut opininya, Alkitab hanya mengandung kesaksian tentang Kristus. Alkitab tidak benar-benar perkataan Kristus. Neo-Ortodoks juga menolak pentingnya berpegang pada kemutlakan kesejarahan Alkitab.

Ajaran Baptis menyatakan bahwa, Alkitab adalah firman Allah, yang berlawanan dengan teori Liberal, Neo liberal, dan Neo Ortodoks. Firman Allah adalah kebenaran yang absolute dan objektif.

Tidak dapat disangkali Alkitab sudah menjadi buku yang paling banyak dibaca, paling banyak diterjemahkan dan buku yang paling laris di dunia di sepanjang zaman, dan bagi milyaran manusia pada zaman ini, Alkitab sudah menjadi sumber iman, kebenaran dan bimbingan. Dalam bahasa Ibrani menggunakan istilah dabar, bahasa Yunani memakai kata logos dan bahasa Latin memakai kata verbum sebagai terjemahan dari kata word (kata atau firman) dalam bahasa Inggris.

Satu-satunya yang dapat meyakinkan kita bahwa Alkitab adalah firman Allah, ialah Roh yang memimpin penulis-penulis Alkitab. Plato pernah berkata, bahwa kitab itu seperti anak piatu. Maksudnya ialah bahwa ayah kitab itu (yakni penulisnya) tidak hadir pada waktu kita membaca kitab, sehingga kerap kali kitab itu 
kita perlakukan sekehendak hati kita sendiri. Akan tetapi Alkitab bukanlah anak piatu. ${ }^{1}$

Roh Kuduslah yang dapat meyakinkan kita bahwa Alkitab adalah Firman Allah yang dapat dipercaya sehingga dengan Alkitab itu kita dapat mengenal Tuhan, mengenal diri sendiri, dan mengenal Tuhan Yesus Kristus. Sebab, tidak pernah nubuat dihasilkan oleh kehendak manusia, tetapi kehendak manusia, tetapi oleh dorongan Roh Kudus, orang-orang berbicara atas nama Allah (2Ptr.1:21).

Santo Hieronymus adalah orang pertama yang memakai istilah bible (sebenarnya dia memakai bahasa Latin: biblia), dan juga merupakan orang pertama yang mengumpulkan versi pertama Alkitab sekitar tahun 396-400 Masehi.

Terjemahan kata Alkitab dalam bahasa Latin yang dipakai oleh Hieronymus adalah Vulgata yang berasal dari kata dalam bahasa Latin vulgus, yang artinya orang biasa. Pada masa itu orang-orang kebanyakan dalam Kekaisaran Romawi, yang tidak berpendidikan, hanya bisa berbicara, membaca dan menulis dalam huruf Latin. Sementara kaum elitenya memahami bahasa Yunani dan bahkan beberapa di antara mereka bisa membaca huruf-huruf Ibrani. ${ }^{2}$ Karena hanya para cendikiawan yang mampu membaca dan menulis dalam bahasa Yunani dan Ibrani pada masa itu, masyarakat umum membutuhkan terjemahan dalam bahasa ibu mereka, yaitu bahasa Latin bagi seluruh Kekaisaran Romawi. Itulah untuk pertama kalinya seluruh Alkitab muncul dalam satu bahasa, dan juga untuk pertama kalinya semua kitab itu disatukan menjadi satu jilid buku. Alkitab, adalah nama kumpulan kitab-kitab yang diakui sebagai kanonik, dan diakui sebagai firman Allah oleh Gereja Kristen. Nama itu, yang berdasarkan

1J. Verkuyl, Aku Percaya (Jakarta: BPK Gunung Mulia, 1995), 24

2John Trigilio dan Kenneth Brighenti, Memahami Segalanya Tentang Alkitab (Batam: Karisma Publising Group, 2007), 11.

3D. Douglas, Ensilopedi Alkitab Masa Kini, vol 1 (Jakarta: OMF 1992), 28 pemakaian kata Yunani Biblia (jamak, bukubuku) bagi keseluruhan kumpulan kitab-kitab itu seolah-olah satu kitab saja. ${ }^{3}$

\section{METODE PENELITIAN}

Penelitian ini dilakukan dengan menggunakan metode analisa teologi biblika dengan melakukan eksegesis untuk menafsirkan atau mengartikan teks-teks yang ada. Selain itu, penelitian ini juga menggunakan metode riset kepustakaan dimana peneliti menggunakan informasi atau data empiric yang telah dikumpulkan oleh orang lain baik dalam bentuk laporan hasil penelitian maupun laporan-laporan resmi yang dapat digunakan untuk riset kepustakaan.

\section{PEMBAHASAN \\ Pengilhaman Alkitab}

Doktrin pengilhaman bukanlah sesuatu yang dipaksakan oleh para teolog terhadap Alkitab. Tetapi merupakan ajaran Alkitab sendiri, suatu kesimpulan yang didapat dari data yang ada di dalamnya. Dan apapun yang dipikirkan mengenai Alkitab, seperti seorang saksi, mempunyai hak untuk menyaksikan apa adanya.

\section{Metode Pengilhaman}

Alkitab diilhami Allah. Kata diilhami Allah berasal dari bahasa Yunani theopneustos yang berarti dimasuki napas Allah. Diilhami Allah berarti Allah memampukan orang-orang yang dipilih-Nya untuk menulis firman Allah tanpa kesalahan (Yer.30:2; 2Tim.3:16-17; 2Ptr.1:19-21). ${ }^{4}$

Tidak semua teolog sepakat mengenai metode pengilhaman Alkitab. Ada dua macam pemikiran tentang hal ini.

Pertama, Teori Mekanis. Teori ini meyakini akan pengilhaman yang penuh, diberikan sekata demi sekata, yaitu bahwa setiap kata dalam Alkitab didiktekan oleh Roh kudus, secara langsung atau tidak langsung. Orangorang tepat menulis apa yang dikatakan Allah

4Sentot Sadono, Pedoman Pernyataan Asas-Asas Kepercayaan Gabungan Gereja Baptis Indonesia dan Pedoman Pelayanan Pejabat Gereja Baptis Indonesia (Semarang: STBI, 2005). 
kepada mereka untuk ditulis. Kedua, Dinamis. Yaitu ilham jenis pikiran, berlawanan dengan ilham sekata demi sekata. Menurut teori ini kata-katanya dipilih oleh penulis, tetapi kebenaran yang dikemukakan datang dari Roh Kudus. ${ }^{5}$ Jadi kedua metode tersebut dapat dibenarkan. Pada dasarnya pemikiran - pemikiran Alkitab diilhamkan. Bagaimana-pun, agar pemikiran dipahami, harus dinyatakan dalam kata-kata.

Bukti penting bahwa Alkitab itu adalah kitab yang diilhamkan yaitu Alkitab itu sendiri. Firman Tuhan itu benar, segala sesuatu dikerjakan-Nya dengan kesetiaan (Mzm.33:4). Berikut ini uraian tentang ayat firman Tuhan sebagai bukti bahwa Alkitab diilhamkan:

\section{Surat 2 Timotius 3:16}

Dalam ayat ini rasul Paulus menyatakan bahwa segenap tulisan diilhami oleh Allah dan berguna untuk banyak hal. Alkitab mengklaim diberikan melalui inspirasi oleh Allah (bd.2Tim.3:16), dihembuskan, dinafaskan Allah. Roh Kudus, penulis Alkitab yang sebenarnya, memampukan para rasul dan para nabi untuk mencatat wahyu Allah dengan suatu cara yang dapat dipercaya secara mutlak. Orang-orang ini dipimpin oleh Roh Kudus sehingga tulisan-tulisan mereka tidak lebih dan tidak kurang sebagai wahyu Allah tanpa kesalahan (2Ptr.1:20, 21).

Allah memipin para penulis sehingga mereka menuliskan pesan-Nya dalam Alkitab. Ada beberapa kata kunci yang penting tentang definisi pengilhaman.

Pertama, kata mengawasi memberi-kan peluang adanya warna-warni hubungan antara Allah dan para penulis dan paham yang beragam. Pengawasan kadangkadang sangat langsung dan ada kalanya kurang, namun senantiasa meliputi penjagaan agar para penulis, menulisnya dengan teliti.

Kedua, kata menyusun menunjukkan, bahwa para penulis bukanlah penulis steno yang pasif yang sekadar

${ }^{5}$ J. Clyde Turner, Pokok-Pokok Kepercayaan Orang Kristen (Bandung: Lembaga Literatur Baptis 1978), 10-11. mencatat apa yang Allah diktekan, tetapi justru sebagai penulis yang aktif menyusun atau mengarang.

Ketiga, tanpa keliru menyatakan penegasan Alkitab sendiri sebagai kebenaran.

Keempat, pengilhaman hanya dikaitkan dengan tulisan aslinya, bukan dengan salinan atau pun terjemahan bagaimana-pun telitinya.

Dalam bahasa Yunani firman Tuhan tentang 2 Timotius 3:16 berbunyi, pasa grafe theopneustos kai ofilimos, yang berarti kalau diterjemahkan secara hurufiah segala tulisan yang dihembuskan oleh Allah dan bermanfaat. Istilah segala tulisan (pasa grafe) menunjuk kembali kepada Kitab Suci (hiera gramata) dalam ayat 15 , sehingga yang dimaksud ialah segala tulisan yang terdapat dalam Kitab Suci. Tulisan-tulisan tersebut dikatakan sudah diilhamkan Allah. Artinya: yang diilhamkan bukan hanya makna, berita atau kata, melainkan sampai kepada proses penulisan. Maka ilham ilahi itu berlaku sehingga huruf-huruf itu disebut suci (hiera grammata) dan kitab itu disebut suci (2Tim. 3:15). Arti harfiah dari diilihamkan ialah dihembuskan. Nafas Allah menunjukan kepada Allah sebagai Pencipta (Mzm.33:6; 104:29-30; Yes.42:5; Kej.2:7; Yoh.20:22). Allah mengirim napas dan Roh-Nya, maka isi dunia tercipta. Apabila dalam kaitan dengan Alkitab Paulus menggunakan istilah napas Allah yang menghembus, maka Paulus ingin menegaskan Alkitab sebagai ciptaan Allah. Allah sendirilah yang menciptakan Alkitab melalui karya Roh Kudus-Nya yang bekerja sama dengan manusia pilihannya (1Kor.3:9). ${ }^{6}$

\section{Surat 2 Petrus 1:16-21.}

Sebab tidak pernah nubuat dihasilkan oleh kehendak manusia, tetapi oleh dorongan Roh Kudus orang-orang berbicara atas nama Allah (2Ptr.1:21). Ayat ini memberitahu dengan jelas, bagaimana Allah memakai penulis untuk menghasilkan Akitab. Roh Kudus mendorong atau mengangkat mereka.

B.B. Warfield dalam bukunya Charles C. Ryrie mengulas, dengan menekankan adanya penyangkalan yang tegas bahwa, nubuat- tidak dihasilkan dari inisiatif manusia. Tiada nubuat yang dihasilkan oleh kehendak manusia. Maka,

6V. Scheunemann, Apa Kata Alkitab Tentang Dogma Kristen (Batu: Departemen Literatur, YPPII, 1988), 97. 
terdapat juga pernyataan yang tegas bahwa sumbernya adalah Allah. ${ }^{7} 2$ Petrus 1:21 menyatakan bahwa Allah memakai manusia dan memberikan kepada kita sebuah Alkitab yang seluruhnya benar.

\section{Sifat Alkitab}

Meskipun paham inspirasi dari Zaman Orthodoksi yang bersifat mekanis sulit kita terima, namun ketegasan mereka tentang sifat-sifat Alkitab patut kita hargai. Ada tujuh sifat kitab suci yang digariskan Menurut V. Scheunemann antara lain:

\section{Infallibilitas Alkitab}

Infallibilitas Alkitab artinya otoritas Alkitab tanpa cacat, tanpa cela, mutlak dan mencakup seluruhnya. Alkitab tidak dapat dikontradiksikan, dilanggar, diabaikan atau dilawan dengan cara apapun tanpa mendapat hukuman.

\section{Inerransi Alkitab:}

Inerransi artinya Alkitab mempunyai kualitas yang bebas dari kesalahan. Alkitab tidak mungkin salah, Alkitab tidak mengatakan yang bertentangan dengan kenyataan, Alkitab mencatat sejarah secara akurat dan sempurna.

\section{Verbal}

Verbal artinya setiap kata dalam Alkitab adalah dinapaskan oleh Allah bersama dengan rancangan gramatikal kalimatnya (sintaksis).

\section{Plenary}

Plenary artinya keseluruhan dari 66 kitab dalam Alkitab sama-sama diinspirasikan, walaupun kegunaan dari wahyu tersebut bervariasi.

\section{Konfluen}

Konfluen (kesesuaian) artinya para penulis Alkitab tidak dipakai sebagai boneka-boneka mekanis. Tetapi Allah sendiri bebicara secara kreatif. Ini berarti bahwa perkataan-perkataan Alkitab merupakan perkataan manusia dan perkataan Allah pada waktu yang sama,

7Charles C. Ryrie, Teologi Dasar, jilid 1 (Yogyakarta: Yayasan Andi, 1991), 92.

8 Scheunemann, Apa Kata Alkitab Tentang Dogma Kristen, 111-112.

9Trigilo dan Kenneth Brighenti, Memahami Segalanya Tentang Alkitab, 61. namun akhirnya berasal dari Allah juga yang bebas dari kesalahan.

\section{Perspicuity}

Perspicuity (ketajaman) artinya doktrin ini mengenai kejelasan Alkitab yang mana, setiap orang yang bisa membaca dapat membaca dan mengerti Alkitab.

\section{Efficax}

Efficax artinya Alkitab mempunyai maksud dan tujuannya. Maksud dan tujuan Alkitab adalah memanggil dan mengantar manusia kepada keselamatan oleh karena kematian dan Kebangkitan Kristus. ${ }^{8}$

\section{Kanonisasi Alkitab}

Salah satu pertanyaan paling kontroversial dalam Alkitab adalah, bagaimana cara menetapkan kitab-kitab mana yang layak dimuat di dalamnya? Dan mengapa ada perbedaan antara Alkitab versi Protestan dan versi Katolik?

\section{Keputusan yang Menetapkan Isi Alkitab}

Di dalam Alkitab sendiri tidak disebutkan kitab-kitab mana yang menjadi bagiannya. Bagaimana beberapa kitab di antara sekian banyak yang ditemukan, yang terpilih menjadi bagian dari Alkitab yang sekarang? Tentu hal ini menjadi pertanyaan kita semua. Menurut John Trigilo dan Kenneth Brighenti adalah karena tradisi iman kristiani seperti gereja Kristen Ortodoks dan Gereja Katolik Roma, yang menilai mereka yang berwewenang mengajar dalam gereja sebagai pihak yang berkompeten untuk menetapkan masalahmasalah tersebut. ${ }^{9}$

\section{Kanonik Vencentius ${ }^{10}$}

Sebagian besar gereja Protestan hanya mengandalkan kewenangan Alkitab saja (sola scriptura) tetapi mereka tetap mempertanyakan kitab-kitab mana yang layak dimuat dalam Alkitab. Mereka memakai sebuah prinsip yang diperkenalkan oleh Santo Vincentius dari Lerins, pada tahun 434 Masehi, yakni kitab-

10Vincentius adalah seorang penulis dan pengkhotbah dari Gaul selatan (sekarang Prancis). Dalam abad kelima ia menulis kanoniknya yang terkenal dalam bab 2 dari Commonitory. Dia menggunakan nama samaran Peregrinus. Dia percaya bahwa sumber kebenaran Kristiani yang hakiki adalah Kitab Suci. Dan bahwa otoritas gereja harus diminta untuk menjamin penafsiran yang benar terhadap Alkitab. 
kitab yabg dipercayai di mana saja, kapan saja, oleh siapa saja.

Rumusan sederhana ini

dimanfaatkan oleh agama-agama yang tidak memiliki doktrin kewenangan gereja untuk menjaga dan menafsirkan kitab suci. Pada dasrnya, rumusan itu tergantung pada apa yang sudah ditetapkan secara universal dihampir sepanjang waktu dan oleh hampir semua orang. Prinsip tersebut juga dikenal dengan nama Kanonik Vincentius.

Septuaginta

Menurut legenda, pada tahun 250

SM, kira-kira tujuh puluh orang cendekiawan Yahudi menghabiskan waktu tujuh puluh hari, menerjemahkan semua teks dari Taurat, kitab para nabi, dan karyakarya tulis lainnya kedalam bahasa Yunani. Hasil terjemahan itu kemudian dinamakan Septuaginta (LXX). Yang diambil dari bahasa Latin artinya nomor tujuh puluh.

Orang-orang Yahudi di Alexandria menyambut Septuaginta dalam bahasa Yunani itu dengan tangan terbuka, tetapi orang-orang Yahudi di Palestina menolaknya, dan menganggap sebagai karya tidak murni karena mereka hanya mengakui versi-versi dalam bahasa Ibrani. Versi bahasa Yunani sudah mengumpulkan empat puluh enam kitab, tujuh di antaranya ditulis dalam bahasa Yunani.

Berbicara mengenai kanon Alkitab berarti berbicara mengenai 66 kitab, yang memenuhi standar tulisan suci yang disebut Alkitab. Kata kanon berarti ukuran atau aturan atau tongkat pengukur. Kanonisasi terakhir terjadi pada tahun 397 M pada konsili Kartago. Pada waktu itu keenam puluh enam kitab (39 PL dan 27 PB) disahkan sebagai totalitas firman Allah. ${ }^{11}$

Hal itu tidak berarti bahwa gereja mempunyai otoritas untuk menentukan apa yang termasuk dan apa yang bukan sungguh-sungguh firman. Gereja tidak menciptakan kanon tetapi gereja mengesahkan dan mengakui apa yang merupakan firman Allah. Gereja sematamata mengesahkan apa yang sudah merupakan Alkitab.

11W. Garry Crampton, Verbum Dey (Surabaya: Momentum, 2004), 44.

\section{Pandangan Keliru Tentang Alkitab}

Ada beberapa pandangan yang salah mengenai inspirasi Alkitab yang akan dibahas di bawah ini.

\section{Dinamis}

Pandangan ini menjelaskan bahwa para penulis Alkitab digerakan oleh Roh Kudus pada suatu tingkat kehidupan Kristen yang lebih tinggi, sehingga mereka dapat melihat hal-hal dengan lebih jelas dari kebanyakan orang percaya. Tetapi hal ini tidak menyebabkan adanya suatu tulisan yang dinapaskan oleh Allah.

\section{Parsial}

Hanya bagian-bagian tertentu Alkitab yang diinspirasikan. Sedangkan bagian-bagian kitab yang lain bukan firman Tuhan. Mereka membedakan antara ajaran-ajaran moral atau religius (di inspirasikan). Sedangkan yang ilmiah atau historis tidak diilhamkan oleh Allah. Alami

Para penulis Alkitab dianggap orangorang yang memiliki kelebihan khusus atau jenius. Karya-karya mereka dianggap sebagai buah pikiran mereka saja dan tidak dipertimbangkan sebagai karya yang berasal usul Ilahi (lih.Yer.1:1, 2, 9).

\section{Dapat Salah}

Pandangan ini beranggapan bahwa Alkitab sendiri di inspirasikan, tetapi tidak tanpa kesalahan. Maka menurut pandangan ini, Allah mungkin menginspirasikan kesalahan. ${ }^{12}$

\section{Orthodoks}

Zaman berganti zaman Reformasi tetapi para teolog Orthodoksi, berhasrat untuk menetapkan sampai selama-lamanya secara obyektif, bahwa Alkitab adalah firman Allah. Untuk itu mereka merumuskan suatu pandangan inspirasi, yang bertujuan menggalangkan segi insani, agar Alkitab tidak dipengaruhi olehnya dan sungguh-sungguh merupakan firman Tuhan yang murni. Mereka mengajar, bahwa pada waktu penulisan Alkitab para nabi dan rasul diilhami sedemikian rupa oleh Roh Kudus, sehingga mereka tidak sadarkan diri. Roh Kudus mendikte kepada mereka kata demi kata, dan mereka hanya berfungsi sebagai alat mati saja, seumpama mesin tik atau seruling yang

12Ibid., 58. 
dibunyikan oleh seorang pemain seruling. Hal ini berarti bahwa manusia tidak berperan sama sekali. ${ }^{13}$

Meskipun para teolog Orthodoksi terdorong oleh cita-cita positif, yang ingin membuktikan Alkitab sebagai Firman Allah, namun cara dan jalan yang mereka tempuh sudah meninggalkan garis Alkitab, sehingga berdampak negatif. Oleh sebab itu pandangan Zaman Orthodoksi tak dapat kita terima. Pandangan inspirasinya disebut Teori Inspirasi Mekanis.

\section{Neo-Orthodoks}

Teologi pada waktu itu umumnya secara kuat menekankan Alkitab. Penekanan tersebut menonjol dalam gerakan yang disebut gerakan NeoOrthodox yang dipelopori oleh Karl Barth. Gerakan Neo-Orthodoksi dimulai segera sesudah Perang Dunia I dan begitu berkembang, sehingga pada akhir Perang Dunia ke-2 sudah berpengaruh sekali. Titik penekanannya adalah pada Alkitab. Bahan pergumulan adalah Allah Alkitab yang menyatakan diri sebagaimana Dia berada, Allah orang Israel, konsep-konsep dan pemikiran Alkitab. ${ }^{14}$ Gerakan NeoOrthodoksi menekankan bahwa iman mulai dengan Allah yang bersabda, dan Alkitablah yang menyaksikan.

Ada aliran-aliran teologi yang lain lagi, yang memang tidak menyetujui pendapat-pendapat khas yang berlaku di kalangan Neo-Ortodoks, namun merekapun semakin lama semakin mendekati Alkitab. Makin bersandar pada isi Alkitab. Makin menekankan Alkitab dan kekhasannya. Telah menjadi suatu mode yang kontras antara pemikiran Alkitab (yang dinilai teologi positif) dengan cara-cara berpikir yang dianggap saingan, misalnya cara berpikir Yunani dan filosofis (yang dalam perbandingan dengan Alkitab dinilai negatif ). ${ }^{15}$

Selain daripada itu, pandangan yang salah yang ditolak kaum Baptis terhadap Alkitab, bahwa Kaum Baptis menolak bahwa Alkitab adalah sebuah buku Ilmu Pengetahuan Alam. Sekalipun

13Ibid., 105. sesungguhnya tidak ada pertentangan antara Alkitab dan ilmu pengetahuan tentang asal-usul dunia. Sekalipun penjelasan Ilmu Pengetahuan Alam tentang dunia masih terus berubah.

\section{KESIMPULAN}

Kita telah memahami berbagai teori pengilhaman Alkitab. Sesungguhnya sikap dan keyakinan terhadap pengilhaman Alkitab tersebut sangat penting. Karena hal itu akan mempengaruhi sikap selanjutnya terhadap Alkitab tersebut. Apa maknanya bahwa Alkitab diilhami Allah? Jika kita sungguh percaya bahwa Alkitab sungguh-sungguh diilhami Allah -terlepas dari bentuk atau teori mana yang diterapkan dari berbagai teori tersebut di atasdan jika percaya serta menerima akan keterlibatan Roh Kudus secara penuh mengontrol dan memimpin para Penulis Alkitab, maka dapat menyimpulkan hal-hal penting berikut ini:

F.F. Bruce menegaskan bahwa selama berabad-abad inspirasi dan kanon Alkitab telah begitu menyatu dalam pemikiran Kristen. Karena itu, Bruce menulis: "... books are included in the canon, it is believed, because they were inspired". (Kitab-kitab dimasukkan ke dalam kanon Alkitab karena dipercayai bahwa kitab-kitab itu diilhami oleh Allah). Sebenarnya, adanya kenyataan bahwa kitabkitab Perjanjian Baru kemudian dimasukkan atau digabungkan dengan Alkitab Perjanjian Lama sebagai bagian dari "segala tulisan" (II Tim.3:16), secara wajar dapat disimpulkan bahwa kitab-kitab Perjanjian Baru tersebut adalah diilhami oleh Allah. Bruce juga menegaskan, "That they were (and are) so inspired is not to be denied". Demikian juga, Packer menulis: "God gave us the New Testament canon, by inspiring the individual books that make it up". (Allah memberikan kepada kita kanon Kitab Suci, dengan mengilhami tiap-tiap Kitab yang membentuk Kitab Suci tersebut).

Bicara soal kesatuan Alkitab ini, menarik sekali apa yang dikatakan Oleh Karl Barth. Dia menegaskan bahwa hanya dalam kesatuan inilah kesaksian Alkitab adalah kesaksian dari wahyu Allah. Demikian juga, Millard Erickson

14James Barr, Alkitab di Dunia Modren (Jakarta: BPK Gunung Mulia, 1993), 7.

15Ibid., 8. 
menyimpulkan bahwa kesaksian yang menyatu dari Penulis-penulis Alkitab menunjukkan bahwa Alkitab berasal dari Allah. Hal ini menurutnya menunjukkan fakta yang kuat dari adanya keterlibatan Allah mengilhami Alkitab tersebut. Apa yang dimaksud dengan infallibility dan inerrancy Alkitab? Infallibility berhubungan dengan pesan Alkitab, bahwa Alkitab tidak akan menyesatkan pembacanya, sedangkan inerrancy menegaskan tentang ketepatan sumber Alkitab tersebut. Kedua hal tersebut sangat penting. Karena itulah Packer berpendapat bahwa penolakan terhadap tuduhan yang diberikan terhadap Alkitab, yaitu bahwa Alkitab memberi pernyataan-pernyataan yang salah, telah menjadi ciri-ciri kaum Injili. Marilah kita perhatikan penegasan dan peringatan Packer berikut:

"As soon as you confict Scripture of making the smallest mistakes, you start to abandon both the biblical understanding of biblical inspiration and also the systematic functioning of the Bible as the organ of God's authority, his rightful and effective rule over His people's faith and life".

(Segera Anda yakin bahwa Kitab Suci membuat kesalahan-kesalahan terkecil maka Anda akan mulai meninggalkan pandangan Alkitabiah tentang pengilhaman Alkitab serta fungsi Alkitab sebagai alat Allah yang berotoritas, kebenaran dan kuasanya atas iman dan hidup umatNya). ${ }^{16}$

Martin Luther, sang reformator telah menegaskan ketidakbersalahan Alkitab ketika dia menghubungkan Alkitab dengan bapak-bapak gereja. Dia menegaskan: "I am ready to trust them, only when they give me evidence for their opinion from Scripture which has never erred". (Saya bersedia mempercayai mereka hanya jika mereka memberikan kepada saya bukti terhadap pendapat mereka dari Kitab Suci, yang tidak pernah bersalah)

Alkitab adalah Firman Allah. Para penulis kitab mendapat pimpinan istimewa dari Roh Kudus. Sebab tidak pernah nubuat dihasilkan oleh kehendak manusia, tetapi oleh dorongan Roh kudus, orang-orang berbicara atas nama Allah (2Ptr.1:21). Penulis-penulis Alkitab hidup pada zaman mereka masingmasing. Mereka hidup dalam alam pikiran dan angan-angan dari zaman mereka masingmasing. Masing-masing mempunyai gaya bahasa, tabiat dan pikiran-pikiran sendirisendiri. Akan tetapi Roh Kudus mendorong mereka berkata-kata dan menulis. Kadangkadang hal ini mereka jalankan tanpa menyadarinya, atau menyadari juga dengan terang dan berkatalah mereka bahwa mereka dikuasai dan didorong oleh Allah.

Oleh Karena Alkitab mempunyai kekuasaan dan kewibawaan Ilahi. Disini Allah sendirilah yang berfirman kepada kita, dan kesaksian Tuhan itu adalah nyata dan dapat dipercaya. Hidup kita alaskan kepadanya sebagai batu alas yang tidak akan goyah.

Alkitab adalah Firman Tuhan, maka berdasarkan keajaiban itu, Alkitab adalah juga perlu sekali untuk kita baca, renungkan, lakukan dan beritakan kepada orang lain.

Kita tidak dapat lepas dari Alkitab. Hanya Alkitablah sumber penyataan khusus Allah, suatu sumber yang cukup, yang mempunyai kekuasan dan berkewibawaan serta yang sungguh perlu sekali bagi kita.

\section{REKOMENDASI}

Memahami Alkitab adalah sebuah hal yang harus ditanamkan sejak dini kepada anakanak, dan memahami alkitab harus sebagai satu kebenaran.

\section{DAFTAR PUSTAKA}

Basden (Ed.), Paul A. Six View On Exploring The Worship Spectrum. Grand Rapids, Michigan: Zondervan

End, Van Den. Harta dalam Bejana. Jakarta: Gunung Mulia, 1987.

Erickson, J Millard. Teologi Kristen Vol 1. Malang: Gandum Mas, 1999.

Fickett, Harold L. Jr. Kepercayaan Kaum Baptis, Suatu Pedoman. Semarang Sekolah Tinggi Teologia Baptis, 1992

${ }^{16}$ J.1. Packer, "Hermeneutics and Biblical

Authority," dalam Johnston, Then Use of the Bible in Doing Theology, 49). 